\title{
Body image in perimenopausal women
}

\section{Katarzyna Szymona-Pałkowska1, Jolanta Adamczuk², Marta Sapalska ${ }^{3}$, Oleg Gorbaniuk ${ }^{4}$, Jacek M. Robak ${ }^{5}$, Janusz J. Kraczkowski ${ }^{5}$}

${ }^{1}$ Department of Clinical Psychology, John Paul II Catholic University of Lublin, Poland

${ }^{2}$ SP ZOZ Nałęczów Clinic, Nałęczów, Poland

${ }^{3}$ Social Insurance Institution (ZUS), Lublin, Poland

${ }^{4}$ Department of Psychological Research Methodology, Institute of Psychology, University of Zielona Góra, Poland

${ }^{5}$ Chair and Department of Obstetrics and Pathology of Pregnancy, Medical University of Lublin, Poland

\begin{abstract}
Introduction: Menopause is the last natural menstruation, followed by a period of 12 months during which no bleeding occurs (WHO). This natural process results from the phasing out of the physiological activity of the ovaries and involves numerous psychological and somatic disturbances. Although perimenopausal ailments are experienced by most women, the correlation between their perception of the bodies and biopsychosocial functioning in the climacteric period is not fully understood. The aim of the study was to determine whether women's body image varies depending on the period of their reproductive life.

Material and methods: 113 women aged 25-60 were examined (both menopausal and postmenopausal) with the control group comprising 58 women. The following scales were used: the Appearance-Related Picture Self-Appraisal Form and the Appearance Self-Appraisal Scale.

Results: The study demonstrated statistically significant differences between the groups on 7 scales and the overall score. It can be said that postmenopausal women, whose ovarian activity has nearly ceased, in comparison with those in the premenopausal and menopausal groups attribute lower importance to the following areas of the body: eyes, nose, mouth, stomach, buttocks, thighs, and calves. The mean values of satisfaction in the three groups under comparison were not statistically different.

Conclusions: The subjects of the postmenopausal group attribute lower importance to different body areas, deriving greater satisfaction from their own bodies.
\end{abstract}

Key words: menopause, postmenopause, self-esteem, body image.

\section{Introduction}

Natural menopause is defined as the cessation of menstruation due to the loss of ovarian follicular activity and is recognized after 12 months of continued amenorrhoea, for which there is no other obvious cause [1]. Typically, this period occurs in women aged between 44 and 55 [2, 3].

Ageing of the body is a natural and irreversible process involving intracellular changes, which the organism can no longer offset. Cells, tissues, organs and whole systems begin to malfunction as a result of a lost body balance. Ageing triggers many somatic changes, and menopause, as its inherent element, involves changes occurring in the psychological and social spheres. Body image is a multifaceted concept encompassing cognitive, perceptual and affective aspects related to the body's appearance, functions and capabilities [4].
Living through menopause is a difficult and complex experience. For women, it is a new phenomenon in their life as they are subjected to numerous negative stimuli. For this reason, the physical and mental importance attached to the body during this period is fully justified. These typical, physical changes associated with ageing negatively impact the psychological sphere and self-acceptance [5]. The literature uses many concepts that pertain to body image: appearance satisfaction, body scheme, satisfaction with one's body, weight or appearance, or preoccupation with one's body [6-8].

A negative body image is often accompanied by low self-esteem [9], while body satisfaction is linked to a greater self-esteem and happiness [10-13]. A positive self-concept may facilitate the development of a positive perception of one's body and serve as a buffer against events that threaten the body image [10]. 
The degree of satisfaction or dissatisfaction with one's appearance breeds individual emotional reactions, and they reflect an affective attitude towards our body [9, 14]. Changes taking place in one's well-being can lead to an altered body image. Attractive people experience greater occupational success and popularity; they also have a higher social self-esteem, better social skills, and better physical and mental health [15].

\section{Objectives}

Body image is not constant. In women, it may be associated with health or stages of the menstrual cycle [16]. A positive body image is a predictor of well-being and a higher quality of life. This project seeks to determine what kind of self-image women have in connection with the changes occurring in their organisms during menopause. We can ask the crucial question: do menopausal and postmenopausal women differ from premenopausal ones in terms of their body image?

Hypothesis 1: Women in the postmenopausal group attach greater importance to specific body parts in comparison with premenopausal and menopausal women.

Hypothesis 2: Women in the postmenopausal group manifest lower satisfaction with specific body parts than those in the premenopausal and menopausal groups.

Hypothesis 3: Women in both the menopausal and postmenopausal groups report greater difficulty accepting their bodies and greater concerns about defects in their appearance.

\section{Justification of the hypotheses}

Since numerous somatic and psychological changes take place during the perimenopausal period, we can ask the question whether this is reflected in body perception and whether a negative attitude to specific aspects of one's figure can be linked to the occurrence of specific symptoms [17]. Some studies have shown that older women are more vulnerable in terms of body image. This applies in particular to obese women, who are more likely to perceive their bodies in a negative light [18].

\section{Material and methods}

\section{Study design and participants}

The study design complies with the guidelines of the Helsinki Declaration, approved by the Bioethics Committee of the Medical University of Lublin. Written consent was obtained from every participant, and each of them had access to the results.

Initially, the study involved 130 women who reported menopausal symptoms (the clinical group) and those who visited a gynecologist for preventive examinations (the control group). In order to qualify for the two groups,
FSH and estradiol levels were measured and a clinical interview was conducted. Also TSH levels were assessed to exclude cases of thyroid dysfunction. In total, due to various co-occurring somatic diseases, 17 women were not qualified for the study. The FSH and estradiol level indexes were obtained only for the purpose of assignment to a study group; they were not correlated with other variables since the standards for measuring hormones in scientific research (biochemical-psychological studies) are very strict, and therefore they are very difficult to perform in ambulatory conditions.

Finally, 113 women aged 25-60 were examined. Most of them were from small towns, and were married or in a stable relationship. All were somatically healthy, and the following conditions had been ruled out: diabetes, hypertension, thyroid diseases, ischemic heart disease, rheumatoid arthritis, or advanced degenerative diseases.

\section{Research fools}

The Appearance-Related Picture Self-Appraisal Form (Rysunkowy Arkusz Samooceny Wyglądu - RASW), authored by Janowski et al. [19], has two sections. It contains a schematic diagram of the human body labelling specific body areas (1-25). A subject is to assign numbers 0-10 to those areas in one column depending on how much a given area is important to her, and in the other in accordance with how satisfied she is with a particular body part (e.g. hair, eyebrows, eyelashes, legs, stomach).

The Appearance Self-Appraisal Scale (Kwestionariusz Samooceny Wyglądu - KSW), by Awruk et al. [20], is based on earlier, similar scales: the Dysmorphic Concern Questionnaire by Jorgensen et al. [21]; the BDD Yale-Brown Obsessive-Compulsive Scale by Phillips et al. [22]; the Body Dysmorphic Disorder Questionnaire by Phillips [23], and the Body Image Disturbance Questionnaire by Cash et al. [24]. The test items were formulated on the basis of diagnostic criteria for a dysmorphic disorder provided by DSM-IV. The questionnaire employs 4 scales: sense of defect in appearance, defect masking, obsessive preoccupation with defect, and defect control. KSW is a method offering high reliability, where Cronbach's $\alpha$ equals 0.98 .

\section{Statistical analysis}

IBM SPSS Statistics version 25 was used for statistical analysis. In the case of the quantitative variables, descriptive statistics were calculated: arithmetic mean and standard deviation. The distribution consistency of the variables with normal distribution was studied using the Shapiro-Wilk test. Since the distributions, including importance of appearance and satisfaction with own appearance, differed significantly from the normal distribution, nonparametric methods were used to verify the hypotheses: the ANOVA Kruskal-Wallis rank test 
was used for more than three groups together with a post hoc test taking account of the Bonferroni correction. The distributions of sense of defect in appearance measures did not differ significantly from the normal distribution, so we used one-way ANOVA. The results of the tests were considered statistically significant when the probability $(p)$ value was $<0.05$.

\section{Results}

Group A comprised 30 menopausal women aged 45-55 ( $M=50.76)$ with $\mathrm{BMI}$ of 25.52 and weighing $48-95 \mathrm{~kg} .13 .5 \%$ of them had vocational education, $48.6 \%$ had secondary education, and $35 \%$ were collegeeducated. All were occupationally active and lived in average socioeconomic conditions.

Group B comprised 25 postmenopausal women aged $56-60(M=59.00)$ with $\mathrm{BMI}$ of 27.13 and weighing $60-98 \mathrm{~kg} .16 .7 \%$ of them had vocational education, $50 \%$ had secondary education, and $12 \%$ were collegeeducated. $56 \%$ of the women were occupationally active, while $45 \%$ were retired.

Group C (control) comprised 58 premenopausal women aged 25-40 with BMI of 23.77 and weighing $48-108 \mathrm{~kg} .10 \%$ of them had vocational education, $42 \%$ had secondary education, and $37 \%$ were college-educated. $85 \%$ of the subjects were occupationally active, while $15 \%$ were unemployed.

\section{Importance of body appearance}

To compare importance of body appearance in the researched groups (hypothesis 1 ), nonparametric tests were used: Kruskal-Wallis $H$ test with a post hoc test.

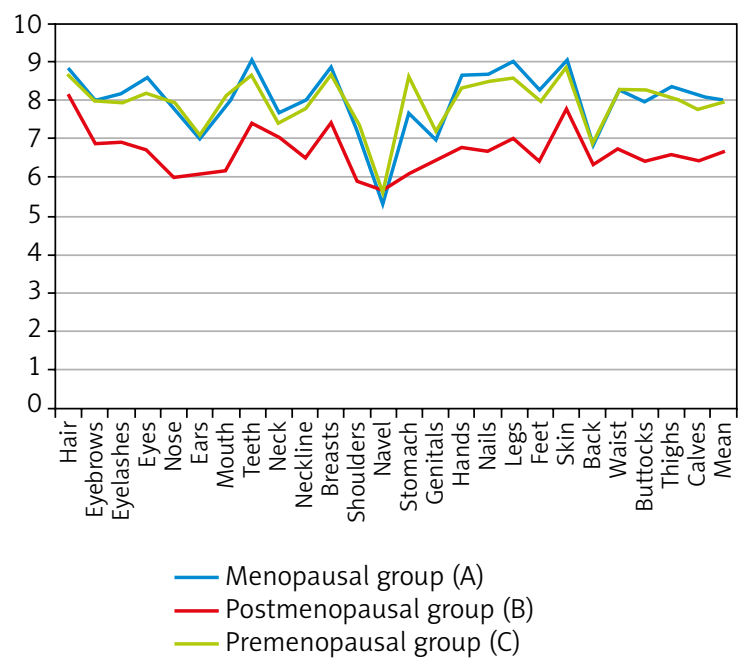

Fig. 1. A graphical representation of importance assigned by women to their body parts in the three groups under comparison
The scores for the importance of body appearance in particular subjects ranged from 0 to 10 . The spread analysis of the values demonstrated that one group recorded minimum and maximum average values of attributed importance, ranging from $M=5.30$ (navel) to $M=9.03$ (skin) and $M=9.08$ (teeth) in the menopausal group (Fig. 1, Table 1).

The groups demonstrated statistically significant differences on 7 scales and the overall score.

It can be seen that group A (menopausal) displays a similar degree of importance attached to various body parts relative to the control group (premenopausal). The women of group A attribute significantly lower importance only to the stomach category $(z=-2.457, p<0.01)$ in comparison with group $C$. The group A subjects, relative to group $B$, attach more importance to: eyelashes $(z=2.513, p<0.01)$, eyes $(z=2.363, p<0.05)$, buttocks $(z=2.361, p<0.05)$, thighs $(z=2.345, p<0.02)$ and calves $(z=2.345, p<0.05)$. The postmenopausal women (group B) ascribe less importance to the following facial areas in comparison with group C: eyes $(z=-2.254$, $p<0.05)$, nose $(z=-2.675, p<0.01)$, mouth $(z=-2.688$, $p<0.01)$, stomach $(z=-3.489, p<0.001)$ and buttocks $(z=-2.380, p<0.05)$ (Fig. 1).

The lines representing importance attributed to particular body areas by the participating women demonstrate that more value is attributed to selected body parts.

\section{Satisfaction with body appearance}

To compare satisfaction with body appearance in the researched groups (hypothesis 2), the Kruskal-Wallis $\mathrm{H}$ nonparametric test was used.

Mean values of satisfaction in the three groups under comparison are not statistically different. Estimated mean values of satisfaction with different body parts range from 5.14 for stomach (the lowest score in the menopausal and the premenopausal groups) to 7.89 for ears (Table 2).

\section{Sense of defect in appearance}

In order to verify the severity of difficulties and concerns about defects in appearance in the groups under comparison (hypothesis 3), the KSW was used. Based on the analysis performed by one-way ANOVA, no statistically significant differences were found between the examined groups with respect to perceived defects in one's body. All of the examined groups showed the highest scores on the sense of defect scale. Differences shown by the defect masking scale were close to statistical significance. The women of the postmenopausal group (B) displayed lower proneness to conceal generally unacceptable aspects of their appearance (Table 3 ). 


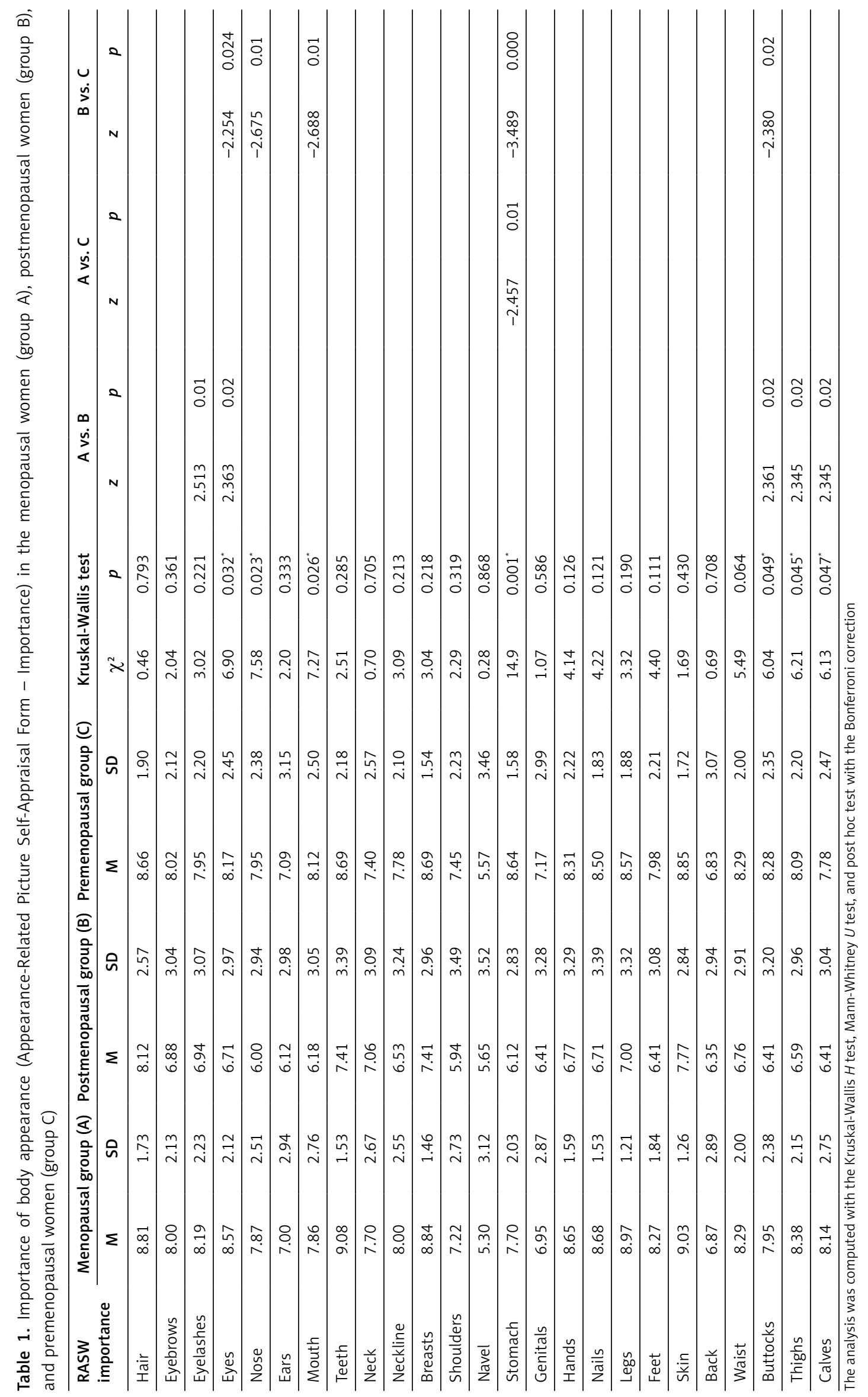


Table 2. Satisfaction with body appearance (Appearance-Related Picture Self-Appraisal Form - Satisfaction) in the menopausal women (group A), postmenopausal women (group B), and premenopausal women (group C)

\begin{tabular}{|c|c|c|c|c|c|c|c|c|}
\hline \multirow{2}{*}{$\begin{array}{l}\text { RASW } \\
\text { satisfaction }\end{array}$} & \multicolumn{2}{|c|}{ Menopausal group (A) } & \multicolumn{2}{|c|}{ Postmenopausal group (B) } & \multicolumn{2}{|c|}{ Premenopausal group (C) } & \multicolumn{2}{|c|}{ Kruskal-Wallis test } \\
\hline & $M$ & SD & M & SD & M & SD & $\chi^{2}$ & $p$ \\
\hline 1. Hair & 7.24 & 2.216 & 6.41 & 2.740 & 6.57 & 2.103 & 1.782 & 0.410 \\
\hline 2. Eyebrows & 7.41 & 1.863 & 6.94 & 2.440 & 7.00 & 2.362 & 0.499 & 0.779 \\
\hline 3. Eyelashes & 6.97 & 1.951 & 7.12 & 2.233 & 7.14 & 2.220 & 0.521 & 0.771 \\
\hline 4. Eyes & 7.27 & 2.535 & 7.12 & 2.060 & 7.60 & 2.280 & 0.975 & 0.614 \\
\hline 5. Nose & 6.54 & 2.662 & 6.88 & 2.472 & 6.79 & 2.183 & 0.294 & 0.863 \\
\hline 6. Ears & 7.89 & 2.183 & 7.24 & 2.705 & 7.57 & 2.370 & 0.477 & 0.788 \\
\hline 7. Mouth & 7.32 & 2.473 & 7.23 & 2.728 & 7.76 & 2.179 & 1.257 & 0.533 \\
\hline 8. Teeth & 6.14 & 2.562 & 6.29 & 2.867 & 6.29 & 2.256 & 0.221 & 0.895 \\
\hline 9. Neck & 7.11 & 1.955 & 6.94 & 2.968 & 7.35 & 2.205 & 0.642 & 0.725 \\
\hline 10. Neckline & 6.89 & 2.310 & 6.77 & 3.192 & 7.29 & 2.111 & 0.703 & 0.704 \\
\hline 11. Breasts & 6.65 & 2.648 & 7.35 & 2.370 & 6.17 & 2.186 & 3.649 & 0.161 \\
\hline 12. Shoulders & 7.11 & 2.011 & 6.65 & 2.668 & 6.90 & 2.075 & 0.403 & 0.818 \\
\hline 13. Navel & 7.00 & 2.541 & 6.35 & 2.737 & 7.09 & 2.289 & 1.743 & 0.418 \\
\hline 14. Stomach & 5.14 & 2.496 & 6.18 & 2.298 & 5.26 & 2.666 & 1.216 & 0.544 \\
\hline 15. Genitals & 6.70 & 2.581 & 6.88 & 2.547 & 7.22 & 2.392 & 1.259 & 0.533 \\
\hline 16. Hands & 6.41 & 2.266 & 6.53 & 2.528 & 7.26 & 2.040 & 3.907 & 0.142 \\
\hline 17. Nails & 6.70 & 2.259 & 6.53 & 2.741 & 7.16 & 2.120 & 1.371 & 0.504 \\
\hline 18. Legs & 6.84 & 2.834 & 6.12 & 2.826 & 6.98 & 1.888 & 1.299 & 0.522 \\
\hline 19. Feet & 6.54 & 2.256 & 6.88 & 2.233 & 7.07 & 1.954 & 0.999 & 0.607 \\
\hline 20. Skin & 6.43 & 2.375 & 6.94 & 1.919 & 6.81 & 1.721 & 0.462 & 0.794 \\
\hline 21. Back & 6.86 & 2.016 & 6.88 & 2.233 & 7.10 & 2.276 & 0.931 & 0.628 \\
\hline 22. Waist & 6.35 & 2.606 & 6.65 & 2.317 & 5.78 & 2.596 & 1.550 & 0.461 \\
\hline 23. Buttocks & 6.03 & 2.432 & 6.94 & 2.331 & 6.48 & 2.422 & 1.251 & 0.535 \\
\hline 24. Thighs & 5.68 & 2.739 & 6.12 & 2.421 & 6.00 & 2.192 & 0.210 & 0.900 \\
\hline 25. Calves & 6.89 & 2.787 & 6.12 & 3.080 & 6.35 & 2.552 & 1.364 & 0.506 \\
\hline
\end{tabular}

The analysis was computed with the Kruskal-Wallis $H$ test and Mann-Whitney $U$ test

Table 3. Sense of defect in appearance in menopausal women (group A), postmenopausal women (group B), and premenopausal women (group C)

\begin{tabular}{lccccccccc}
\hline Appearance Self-Appraisal Scale & \multicolumn{2}{c}{$\begin{array}{c}\text { Menopausal } \\
\text { group (A) }\end{array}$} & \multicolumn{2}{c}{$\begin{array}{c}\text { Postmenopausal } \\
\text { group (B) }\end{array}$} & \multicolumn{2}{c}{$\begin{array}{c}\text { Premenopausal } \\
\text { group (C) }\end{array}$} & $\boldsymbol{F}$ & $\boldsymbol{p}$ \\
& $\mathbf{M}$ & SD & $\mathbf{M}$ & SD & $\mathbf{M}$ & SD & \\
\hline Sense of defect in appearance & 39.44 & 12.84 & 35.39 & 16.278 & 43.53 & 17.331 & 2.025 & 0.137 \\
\hline Defect masking & 11.44 & 3.87 & 9.22 & 4.278 & 11.84 & 3.890 & 3.053 & $0.05^{*}$ \\
\hline Obsessive preoccupation with appearance & 6.44 & 2.40 & 6.39 & 3.202 & 6.96 & 3.151 & 0.469 & 0.627 \\
\hline Defect control and checking & 8.47 & 2.16 & 7.44 & 3.312 & 8.95 & 3.032 & 1.951 & 0.147 \\
\hline Overall & 65.81 & 19.21 & 58.44 & 26.653 & 71.28 & 26.003 & 2.056 & 0.133 \\
\hline Analysis computed by 1-way ANOVA & & & & & & & & &
\end{tabular}

\section{Discussion}

Studies presented in the literature of the subject point to a significant correlation between satisfaction with particular body areas and the quality of life [2527]. A negative self-image exerts an influence on somatic and psychological health. The appraisal of one's body image can be useful in mental health prophylaxis of women who experience the transitional period.

The hypotheses postulated at the beginning were not fully supported because the study results were different from the expected ones.

It was assumed that the subjects of the postmenopausal group should report higher importance of specif- 
ic body parts than the premenopausal and menopausal groups (hypothesis 1). We observed that the women in the postmenopausal period, relative to the premenopausal (C) and menopausal group (A), attribute less importance to their appearance. This applies to a reduced importance attached to the facial areas (nose, mouth), parts of the limbs (hands, nails, feet), and parts typically associated with femininity (breasts, stomach, waist, buttocks, thighs). The women in the menopausal phase exhibited one significant difference in importance attributed to their stomachs, which may be attributable to excess fat in that area [27]. The women in both the control group and the menopausal group attribute greater importance to their bodies.

Also, hypothesis 2, positing that postmenopausal women will manifest lower satisfaction with specific body parts than those in the other two groups, was not confirmed. There are no significant differences in satisfaction with body appearance among the examined women. All of the examined groups manifested moderate satisfaction with specific regions of their bodies. The similarity between the premenopausal and the menopausal group is probably due to the fact that in women aged 45-55 the transition to menopause affects their appearance less intensely.

Body image constitutes an important element of self-esteem since it is a mental representation of our body perception. Body image encompasses our beliefs about own appearance (actual self), desired appearance (ideal self), and what the body should look like (ought self). Discrepancies between these aspects of the selfgive rise to emotions of varying intensity and value. Greater discrepancy implies a higher possibility of disappointment and dissatisfaction with our body [6]. It is interesting that the postmenopausal women manifested the lowest discrepancies between Importance and Satisfaction concerning specific body areas [25, 26]. Considering the age and the changes, the women became adapted to a changed figure, attaching less importance to various parts of their body. Apparently, with age women feel less concerned about the need to be physically attractive. According to Frazoi, a perception of one's body in the light of a process of consecutive changes, opportunities and fulfilled roles contributes to satisfaction with one's appearance [28]. Over time, the majority of the examined women revealed a tendency to accept changes occurring in their bodies, which enabled them to derive satisfaction from this stage of their life [29]. This observation suggests that with the passage of time they evaluated their bodies in terms of its function and health rather than the physical appeal; therefore they experienced fewer negative emotions associated with their appearance than we would assume [7, 30].

The premenopausal women, i.e. those in the youngest group, were more critical about themselves (a disparity between importance and satisfaction). This can give rise to negative feelings, but it is also an incentive for more intense physical activity, healthy habits, dieting and activities intended to enhance their attractiveness.

Hypothesis 3 envisaged that women of the menopausal and postmenopausal groups will display greater concerns about appearance defects.

Nowadays society is driven by great concerns about appearance. When the ageing time sets in, many people do not accept changes in their appearance and undertake various steps to conceal or eliminate beauty defects. This assumption was borne out only partially. The lowest tendency to carry out various activities intended to conceal the less acceptable body parts was displayed by the women in the postmenopausal group. As observed earlier, these women have lower expectations concerning their body looks - so they have less desire to hide their bodies from view (Table 3). This, however, was not confirmed by the whole perimenopausal group.

Women in the postmenopausal period become adapted to a changed appearance caused by menopause (lower skin flexibility, wrinkles, and accumulated fat tissues). They demonstrate the least discrepancy between the importance they attribute to their appearance and their satisfaction with it. This means that over time the perception of one's body and its acceptance evolve. This is beneficial for emotional well-being but has little stimulating function for physical activity and actions undertaken to promote one's health. In accordance with our estimations, during this time many women are overweight and take little care about their health; for example, they follow a wrong diet [27, 31]. Research done by Beyazit and Sahin indicates that postmenopausal women derive less satisfaction from their sexual activity [32]. In relation to our results, this can suggest that women may attribute less importance to their body owing to their decreased sexual satisfaction. Less satisfaction causes them to avoid sexual contact, and as a result they feel the pressure to care about their bodies. Health workers managing women in the period of menopausal changes can benefit from these results. It is proposed that such women should be encouraged to change their lifestyle (diet, physical activity, recreation) and to use isoflavones, calcium, vitamin D and inulin, as these can reduce the adverse symptoms of menopause [33], all of which have a positive influence on their self-image and, as a result, the quality of life.

\section{Conclusions}

The postmenopausal women attach less importance to different areas of the body than women in the premenopausal and menopausal groups.

Women from the postmenopausal group show a similar level of satisfaction with their bodies as in the other compared groups. 
Lower importance attributed to certain areas of the body and a similar level of satisfaction with these areas are a manifestation of adaptation to changes resulting from the aging process in general, part of which is menopause. This factor may, however, be an incentive to change one's lifestyle, i.e. take greater care of their appearance and become more physically active. The potential to make generalizations about the research results is limited due to the size of the study group. Our research has focused on comparing women in the premenopausal and menopausal periods, who have a similar mood and do not suffer from hormonal disorders of the thyroid gland. The study group was carefully selected using medical criteria, which restricted the group size. Further research should be carried out on a larger study group.

\section{Acknowledgement}

The research was funded by the means of Medical University of Lublin's statutory activity.

\section{Disclosure}

The authors report no conflict of interest.

\section{References}

1. World Health Organization. The World Health Report - Fighting disease, fostering development. Report of Director-General. Geneva 1996.

2. Bręborowicz G (ed.). Położnictwo i ginekologia. [Obstetrics and gynaecology]. PZWL, Warszawa 2006.

3. Kaczmarek $M$. Determination of the age of natural menopause in a population of Polish women. Prz Menopauzalny 2007; 2: 77-82.

4. Pearcea G, Thøgersen-Ntoumanib C, Duda J. Body image during the menopausal transition: a systematic scoping review. Health Psychol Rev 2014; 8: 473-489.

5. Lindh-Astrand L, Hofmann M, Hammar M, et al. Women's conception of the menopausal transition - a qualitative study. J Clin Nurs 2007; 16: 509-517.

6. Głębocka A. Niezadowolenie z wyglądu a rozpaczliwa kontrola wagi. [Dissatisfaction with appearance versus desperate attempts to control weight]. Impuls, Kraków 2009.

7. Schier K. Piękne brzydactwo. Psychologiczna problematyka obrazu ciała i jego zaburzen. [The beautiful ugly thing. Psychological analysis of body-image and its disturbances]. Scholar, Warszawa 2010.

8. Cash TF, Pruzinsky T. Body Image. A Handbook of Theory, Research, and Clinical Practice. Guilford Press, New York 2002

9. Brytek-Matera S. Obraz własnego ciała u otyłych kobiet: przyczyny i stopień niezadowolenia, związek z obniżoną samooceną i strategiami radzenia sobie ze stresem. [Body image in obese women: causes and degree of dissatisfaction, relation between low self-esteem and stress coping strategies]. Psychiatr Pol 2010; 44: 267-275.

10. Cash TF. Cognitive Behavioral Perspectives on Body Image. In: Body image: A handbook of theory, research, and clinical practice, Cash TF, Pruzinsky T (eds.). Guilford Press, New York 2002: 38-46.

11. Bielawska-Batorowicz E. Temperament, personality versus frequency and intensity of menopausal symptoms. Prz Menopauzalny 2007; 2: 70-76.

12. Cash TF, Fleming E. Body image and social relations. In: Body Image. A handbook of theory, research and clinical practice, Cash TF, Pruzinsky T (eds.). The Guilford Press, New York 2002: 277-286.
13. Polivy J, Herman CP, Trottier K, et al. Who are you trying to fool: Does weight underreporting by dieters reflect self-protection or self-presentation? Health Psychol Rev 2013; 8: 319-338.

14. Van den Berg P, Thompson JK. Self-schema and social comparison explanations of body dissatisfaction: A laboratory investigation. Body Image 2007; 4: 29-38.

15. De Preester H, Knockaert V. Body Image and Body Schema. Interdisciplinary perspectives on the body. Advances in Consciousness Research. John Benjamins Publishing Co, Amsterdam 2005.

16. Bloch A. Self-awareness during the menopause. Maturitas 2002; 41: 61-68.

17. Price B. The older woman's body image. Nurs Older People 2010; 22 31-36.

18. Lewis DM, Cachelin FM. Body image, body dissatisfaction, and eating attitudes in midlife and elderly women. Eat Disord 2001; 9: 29-39.

19. Janowski K, Staniewski M. Kwestionariusz Samooceny Wyglądu konstrukcja metody do pomiaru symptomów dysmorfobicznych. [Appearance-Related Self-Appraisal Form - the structure of dysmorphic symptoms measurement method]. II Ogólnopolska Interdyscyplinarna Konferencja Naukowa „Psychologia w medycynie - Medycyna w psychologii”. Jakość życia w zdrowiu i chorobie. Lublin, 23-24 września 2011.

20. Awruk K, Janowski K, Staniewski M. Kwestionariusz Samooceny Wyglą$\mathrm{du}$ - konstrukcja metody do pomiaru symptomów dysmorfofobicznych. II Ogólnopolska Interdyscyplinarna Konferencja Naukowa „Psychologia w medycynie - Medycyna w psychologii”. Jakość życia w zdrowiu i chorobie. Lublin, 23-24 września 2011.

21. Jorgensen L, Castle D, Roberts C, et al. A Clinical Validation of the Dysmorphic Concern Questionnaire. Aust N Z J Psychiatry 2001; 35: 124-128.

22. Phillips KA, Hollander E, Rasmussen SA, et al. A severity rating scale for body dysmorphic disorder: development, reliability, and validity of a modified version of the Yale-Brown Obsessive Compulsive Scale. Psychopharmacol Bull 1997; 33: 17-22.

23. Phillips KA. Understanding body dysmorphic disorder: an essential guide. Oxford University Press, Oxford 2009

24. Cash TF, Phillips KA, Santos MT, et al. Measuring "negative body image": Validation of the Body Image Disturbance Questionnaire in a non-clinical population. Body Image 2004; 1: 363-372

25. Jafarya F, Kiumars F, Abdollah S, et al. Quality of life and menopause: Developing a theoretical model based on meaning in life, self-efficacy beliefs, and body image. Aging Ment Health 2011; 15: 630-637.

26. Cunningham DA. Application of Roy's adaptation model when caring for a group of women coping with menopause. J Community Health Nurs 2002; 19: 49-60

27. Janicka K. Jakość życia kobiet w okresie średniej i późnej dorosłości. Acta Universitatis Lodziensis. Folia Psychologica 2014; 18: 67-84.

28. Frazoi SL. The body as object versus the body as process: gender differences and gender considerations. Sex Roles 1995; 33: 417-437.

29. Sikorska I. Doznaję i poznaję, czyli ciało osobowe. In: Ciało: zdrowie i choroba. Brachowicz M, Tylikowska A (eds.). Towarzystwo Naukowe KUL JPII, Lublin 2011: 61-72.

30. Deeks A, McCabe MP. Well-being and menopause: An investigation of purpose in life, self-acceptance and social role in premenopausal, perimenopausal and postmenopausal women. Qual Life Res 2004; 13: 389398.

31. Sarri G, Davies M, Lumsden MA, Guideline Development Group. Diagnosis and management of menopause: summary of NICE guidance. BMJ 2015; 12: 351.

32. Beyazit F, Sahin B. Determining the factors influencing the intimate relationship between sexual satisfaction and dyadic adjustment in postmenopausal women. Prz Menopauzalny 2018; 17: 57-62.

33. Vitale SG, Caruso S, Rapisarda AMC, et al. Isoflavones, calcium, vitamin $D$ and inulin improve quality of life, sexual function, body composition and metabolic parameters in menopausal women: result from a prospective, randomized, placebo-controlled, parallel-group study. Prz Menopauzalny 2018; 17: 32-38. 